\title{
Pollutants in sewage effluent and sludge and their impact on downstream water quality: a case study of Malamulele sewage plant, South Africa
}

\author{
C. Baloyi ${ }^{1}$, J. R. Gumbo ${ }^{2}$ \& C. Muzerengi ${ }^{3}$ \\ ${ }^{1}$ Department of Ecology and Resources Management, \\ University of Venda, South Africa \\ ${ }^{2}$ Department of Hydrology and Water Resources, \\ University of Venda, South Africa \\ ${ }^{3}$ Department of Mining and Environmental Geology, \\ University of Venda, South Africa
}

\begin{abstract}
The study assessed the quality of the influent, effluent, sludge of the Malamulele Wastewater Treatment Plant (MWTP) and its impact on the water quality of Mandzoro River. In the effluent discharge, the levels of iron, zinc, copper and lead were $0.5 \mathrm{ppm}, 0.1 \mathrm{ppm}, 0.05 \mathrm{ppm}$ and $0.02 \mathrm{ppm}$ respectively. These heavy metals were also found in the dried sludge. The chemical analysis for phosphates and nitrates showed that they were absent from the upstream section but were present in the downstream section at phosphates $(20 \mathrm{ppm})$ and nitrates $(9 \mathrm{ppm})$. A high concentration of chloride was found in the effluent. The river health assessment, based on the absence or presence of certain macroinvertebrates, showed a presence of pollution resistant aquatic macroinvertebrates, the Psychodidae and Thiaridae which were found in the downstream, but were absent in the upstream.
\end{abstract}

Keywords: nutrients, water quality, wastewater treatment plant, heavy metals, Psychodidae, Thiaridae. 


\section{Introduction}

The accelerated deterioration of river water quality mostly results from the discharge of ever increasing quantities of untreated or partially treated effluent [1]. The effluent contains a variety of pollutants such as heavy metals, pathogens and nutrients, phosphates and nitrates. Mathee and Von Schirnding [2] noted that the presence of heavy metals such as lead $(\mathrm{Pb})$ can cause abnormal behaviour, especially in children. Thus, the presence of heavy metals in effluent has been used as an indicator of the effective removal in the wastewater treatment system [3]. This involves the removal of heavy metals (in very low levels) from domestic wastewater by the use of microorganisms through a process of biosorption/bioaccumulation [4].

Another concern with sewage effluent is the level of nutrients they contain. Anthropogenic nutrient enrichment of freshwater resources is now a global water resource problem. It is most evident in highly populated and developed areas where waterborne sewage system and agricultural practices contribute large amounts of nutrients into the receiving natural water system. The nutrients promote growth of algae in receiving systems causing a wide array of water quality problems. South Africa has some of the most highly nutrient enriched surface waters in the world (Davies and Day [5]). These nutrients have to be removed. The removal process involves bioconversion of nitrates to nitrogen by bacteria, if the sewage plant was designed to provide enough oxygen and a long enough "sludge age" to develop these slow-growing types of organisms [6]. Phosphorous removal is most commonly done by designing an activated sludge system that promotes the development of certain types of bacteria which have the ability to accumulate excess phosphorus within their cells. These methods mainly convert dissolved phosphorus into particulate form.

Macro invertebrates have been used to assess the levels of toxic chemicals in river systems. Invertebrate communities respond relatively quickly to localised conditions in a river and changes in water quality can easily affect their biodiversity [7, 8]. The Mandzoro River and streams in Malamulele area form a vital part in community livelihood system such as the cultivation of vegetables and fruits and fishing in some places along the river [9]. The major objective of the study was to assess the pollutants in sewage effluent, sludge and its impact on downstream water quality of Mandzoro River.

\section{Materials and methods}

\subsection{Study and sampling areas}

The study was undertaken at Malamulele Wastewater Treatment Plant (MWTP) which is located at Malamulele, section $\mathrm{C}$ and along the Mandzoro River, both under the authority of the Thulamela Local Municipality, Vhembe District (Figure 1). A total of 56 water samples were collected between October 2007 and January 2008. 


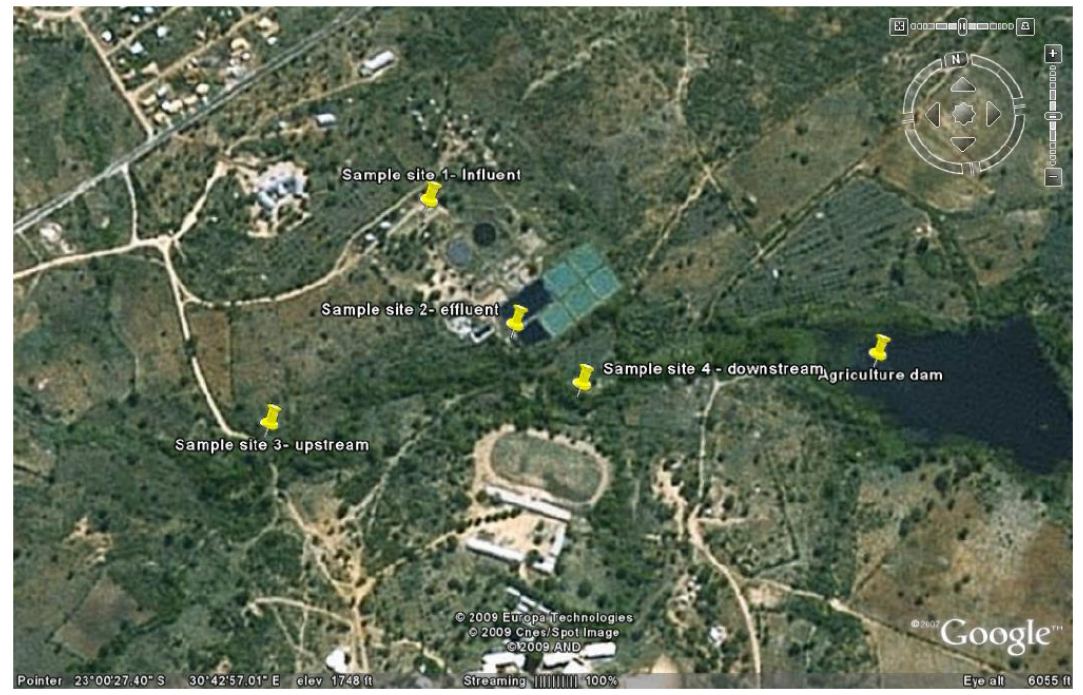

Figure 1: The location of the study area within Malamulele Town (Google earth, 2009).

\subsection{Sampling methods and analysis}

\subsubsection{Sludge and water quality analysis}

Water samples were collected and preserved in $250 \mathrm{ml}$ plastic bottles from both the influent and effluent sections of the Malamulele Wastewater Treatment plant (MWTP) and along Mandzoro River, according to the procedure of APHA [10]. The dried sludge samples were collected from drying beds. The water and sludge samples were transported to the laboratory in a cooler box.

The sludge samples were first dried at room temperature, crushed and then sieved by a Laboratory test sieve with an aperture of $500 \mu \mathrm{m}$ (Endecotts Ltd, London, England). The sieved sludge $(1 \mathrm{~g})$ was weighed on an ESJ-120 balance (Adam Equipment Co. Ltd, London, England) and the nitric-perchloric acid digestion method used by Hseu et al. [11] was followed. The cooled solution was then transferred to a $100 \mathrm{ml}$ volumetric flask and made to the mark with distilled water.

The acidified samples were analysed by Varian Spectra AA 110 Flame Atomic Absorption Spectrometer (220/880 series) and a deuterium background corrector was used to determine the total concentration of $\mathrm{Pb}, \mathrm{Cd}, \mathrm{Zn}, \mathrm{Fe}$ and $\mathrm{Cu}$ according to the procedure of Standard Methods for the Examination of Water and Wastewater (APHA [10]). All chemical analyses were conducted in triplicate.

The Ion Chromatographic analysis (IC) was conducted with a 761 Compact Metrohm Ion Chromatography equipped with an air-actuated 8 port injection valve with $20 \mathrm{uL}$ sample loop, was used to determine the following anions: $\mathrm{Cl}^{-}$; 
$\mathrm{Br}^{-} ; \mathrm{NO}_{3}{ }^{-} ; \mathrm{NO}_{2}{ }^{-} ; \mathrm{PO}_{4}{ }^{3-}$ and $\mathrm{SO}_{4}{ }^{2-}$. The eluent mixture was prepared according to the manufacturer's procedure. The IC analysis was conducted in triplicate.

The physical parameters, dissolved oxygen (DO) was determined with DO meter model OXI 597 - S (Wissenschaftlich-Technische Werkstätten GmbH), electrical conductivity (EC) and $\mathrm{pH}$ with combination $\mathrm{pH}$ meter (Eutech Instruments, Singapore).

\subsubsection{South African Scoring System Version 5 (SASS5)}

The SASS5 procedure by Dickens and Graham [12] was followed to collect data on the aquatic macroinvertebrates. The sampling was done twice in each sample site (Upstream and Downstream) on October 2007 and January 2008 and the SASS5 score sheets were filled accordingly.

\subsection{Data statistical analysis}

Microsoft Excel 2003 was used to analyse the data and prepare graphs.

\section{Results and discussion}

\subsection{Comparison of water quality of Mandzoro River and wastewater from Malamulele Wastewater Treatment Plant}

The water quality data for the upstream and downstream sections of Mandzoro River were different. They showed that the water quality deteriorated downstream of the wastewater discharge point (Table 1). The mean saturation percentage for both sections of the river was below the DWAF saturation percentage which is between $80-120 \%$ (DWAF [13]). The upstream oxygen saturation percentage was within the acceptable quality range according to Koning and Ross [14] in comparison to the turbid Modder River and Singh et al. [15], who reported that dissolved oxygen (DO) of less than $5 \mathrm{mg} / \mathrm{l}$ may adversely affect aquatic life. Therefore, downstream water quality was not acceptable because its oxygen saturation was lower than $60 \%$.

Table 1: Comparison of water quality of Mandzoro River and wastewater from Malamulele WWTP.

\begin{tabular}{|c|c|c|c|c|}
\hline $\begin{array}{l}\text { Water quality } \\
\text { parameters }\end{array}$ & 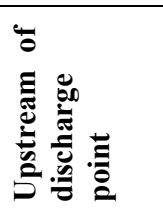 & 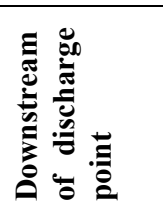 & 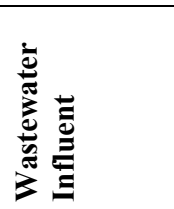 & 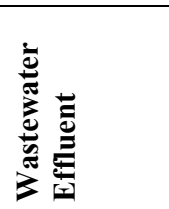 \\
\hline $\begin{array}{l}\text { Dissolved oxygen \% } \\
(\mathrm{ppm})\end{array}$ & $\begin{array}{l}60 \% \\
(5.0 \pm 0.64)\end{array}$ & $\begin{array}{l}50 \% \\
(4.1 \pm 0.24)\end{array}$ & $0.8 \pm 0.29$ & $1.6 \pm 0.4$ \\
\hline $\mathrm{pH}$ & $6.9 \pm 0.24$ & $6.7 \pm 0.33$ & $6.7 \pm 0.21$ & $6.7 \pm 0.33$ \\
\hline $\begin{array}{l}\text { Electrical conductivity } \\
(\mathrm{mS} / \mathrm{m})\end{array}$ & $8.96 \pm 4.2$ & $13.88 \pm 6.5$ & $27.99 \pm 13.8$ & $21.36 \pm 10.5$ \\
\hline
\end{tabular}


The water quality of the downstream section of Mandzoro River deteriorated probably as a result of discharge of poor quality effluent from Malamulele Wastewater treatment Plant (Table 1). The DO in the effluent was $1.6 \mathrm{ppm}$, which was very low compared to $4.0 \mathrm{ppm}$ in the downstream section of Mandzoro River. When effluent was mixed with downstream water, the oxygen demand was raised due to the introduction of oxygen demanding substances in the downstream. Consequently, the DO decreased leading to an oxygen saturation percentage of $25 \%$ of the effluent which is considered to be very low to the South African effluent standard of $75 \%$ (Table 2) [5].

The lower level of oxygen in the effluent was due to discharged effluent with high concentration of nutrients. These nutrients are known for encouraging the growth of algae and other phytoplankton which required oxygen during their growth and decay, thus contributing to less available oxygen in the vicinity of the downstream sample point (Table 1). Furthermore, the decomposition or decay of organic material requires the use of oxygen, which also resulted in less oxygen in the vicinity. In the upstream where there was little or no discharged effluent, the DO was high. The $\mathrm{pH}$ in the upstream was 6.9 , which is very close to neutral point, yet the other sampling point had a $\mathrm{pH}$ of 6.7 respectively within the DWAF effluent standards (Tables 1 and 2). Thus, at this $\mathrm{pH}$ range, the water was suitable for human consumption and irrigation (DWAF [16]). According to O'Loughlin et al. [17]) $\mathrm{pH}$ of this range is not detrimental to aquatic environment because it does not encourage the dissolution of toxic heavy metals. The $\mathrm{pH}$ of the effluent was not comparable to the $\mathrm{pH}$ of 7.5 as reported by Fatoki et al. [18]) for the Kieskammahoek Wastewater Treatment Plant (KWTP).

The average electrical conductivity of the downstream section of Mandzoro River $(13.88 \mathrm{mS} / \mathrm{m})$ was almost double that of the upstream section (Table 1). This may possibly be accredited to the release ions such as chloride, from dissolved solids. The mean chloride concentration of the downstream section (24.1 ppm) was almost double the concentration of the upstream section. Electrical conductivity of both upstream and downstream of Mandzoro River was higher than that of Klein Modder River $(5.2 \mathrm{mS} / \mathrm{m})$ and the salinized Vaal River $(5.3 \mathrm{mS} / \mathrm{m})$ (Koning and Ross [14]). According to Dallas and Day [19] electrical conductivity is not a human and aquatic health concern, however, it can serve as an indicator of other water quality problems.

The mean electrical conductivity of the effluent was $21.36 \mathrm{mS} / \mathrm{m}$ and was within the level required by the South African effluent standard (Table 2). Nevertheless, the effluent was contributing to the accumulation of dissolved solids in the downstream section, hence increasing the electrical conductivity therein. The findings therefore, concur with the observations by Koning and Ross [14] and Fatoki et al. [18] that the electrical conductivity of the downstream section of the discharge point was higher.

The source of chloride in sewage water is usually from household sources where salt is used for food seasoning. The mean chloride concentration in the downstream section of the Mandzoro River was $24.1 \mathrm{ppm}$ which was double the upstream section (Table 1). According to DWAF's [16]) target water quality guideline, this level of concentration is suitable for human and livestock 
consumption, but not suitable for irrigation. The chloride level of $25 \mathrm{mg} / \mathrm{l}$ of the Kieskamma River was similarly attributed to the release of partially treated effluent (Fatoki et al. [18]). The findings of the chloride concentration in the effluent in this observation have contributed to the increase in chloride levels in the downstream water (Figure 2A). Prior to discharge, the final effluent was chlorinated to ensure that it was microbiologically free of pathogenic organisms and this may have contributed to the further increase in chloride levels (Figure 2B).
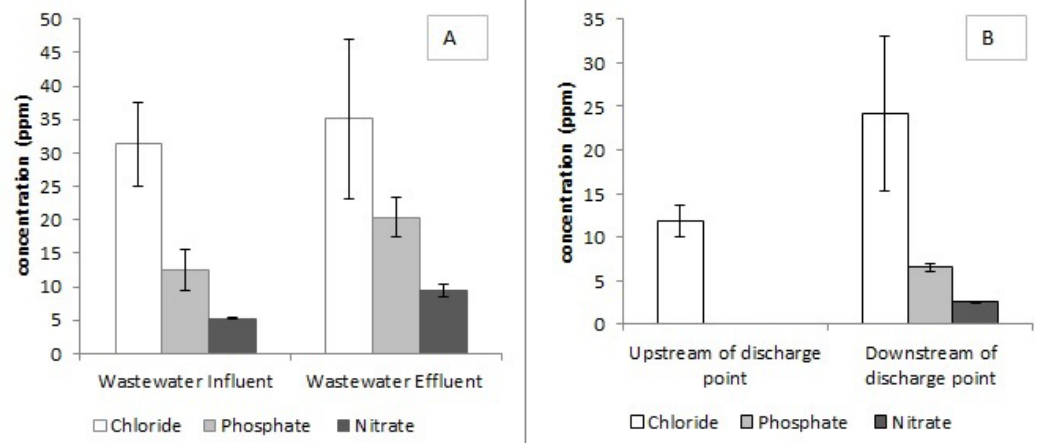

Figure 2: The level of anions in the (A) wastewater comparison of influent and effluent and (B) water quality of Mandzoro River.

The chemical analysis for phosphates and nitrates showed that they were absent from the upstream discharge point but increased downstream (Figure 2). The levels of phosphates and nitrates exceeded the DWAF standards for effluent discharge including the special phosphate standard (DWA [20]), thus Malamulele wastewater treatment plant may not be able to reduce the nitrates and phosphates. These nutrients may possibly contribute to eutrophication over the coming years. Eutrophication is a natural process or a human-induced activity that leads to nutrient enrichment of water bodies with nitrates and phosphates, which in turn promote the excessive growth of aquatic weeds and cyanobacteria blooms (Makhera et al. [21] and Codd [22]). Hence, the likely occurrence of eutrophication can only be prevented through the implementation of drastic measures that reduce the associated human activities detrimental to water bodies.

\subsection{The metal composition of the sludge and wastewater}

The heavy metals in the sludge were mainly composed of iron, zinc, copper, lead and cadmium (Figure 3). These metals in the sludge were found in the following increasing sequence $\mathrm{Cd}<\mathrm{Pb}<\mathrm{Cu}<\mathrm{Zn}<\mathrm{Fe}$ at $\mathrm{pH}$ 6.7. This order was slightly different to the one found by Chipasa [3] of $\mathrm{Zn}<\mathrm{Pb}<\mathrm{Cu}<\mathrm{Cd}$ at $\mathrm{pH} 7$ to 9. This confirmed the notion that the higher and heavier metal in the influent stream, the 
Table 2: Comparison of Malamulele Wastewater treatment Plant effluent quality and DWAF standards.

\begin{tabular}{|l|c|c|c|}
\hline Parameters & $\begin{array}{l}\text { Malamulele } \\
\text { WWTP } \\
\text { Effluent } \\
\text { Quality }\end{array}$ & $\begin{array}{l}\text { Special } \\
\text { Effluent } \\
\text { Standard }\end{array}$ & $\begin{array}{l}\text { General } \\
\text { Effluent } \\
\text { Standard }\end{array}$ \\
\hline Dissolved Oxygen (\%) & 25 & 75 & 75 \\
\hline $\mathrm{pH}$ & $6.3-7.2$ & $5.5-7.5$ & $5.5-9.5$ \\
\hline Electrical Conductivity (mS/m) & 21.3 & 25.0 & 25.0 \\
\hline $\mathrm{Cl}^{-}(\mathrm{ppm})$ & 35 & $\#$ & $\#$ \\
\hline $\mathrm{PO}_{4}{ }^{3-\mathrm{P}(\mathrm{ppm})}$ & 20 & 1 & $\#$ \\
\hline $\mathrm{NO}_{3}{ }^{-\mathrm{N}}(\mathrm{ppm})$ & 9 & 1 & $\#$ \\
\hline $\mathrm{Pb}^{(\mathrm{ppm})}$ & 0.022 & 0.1 & 0.1 \\
\hline $\mathrm{Cu}(\mathrm{ppm})$ & 0.05 & 0.02 & 1 \\
\hline $\mathrm{Fe}(\mathrm{ppm})$ & 0.5 & 0.03 & $\#$ \\
\hline $\mathrm{Zn}(\mathrm{ppm})$ & 0.1 & 0.3 & 5 \\
\hline
\end{tabular}

NB.: $\mathrm{PO}_{4}{ }^{3-} \mathrm{P}$ - soluble phosphates, \# - Parameters that are not set in the standard guideline.

higher the rate of its removal. The concentration of the heavy metals in the influent was found in this increasing sequence; $\mathrm{Pb}<\mathrm{Cu}<\mathrm{Zn}<\mathrm{Fe}$ ( $\mathrm{Cd}$ was not detected) at $\mathrm{pH}$ 6.7. Cd was probably in low concentration below the detection limit of $<0.1 \mathrm{ppm}$. The origin of the heavy metals, $\mathrm{Cu}, \mathrm{Zn}$ and $\mathrm{Fe}$ in the wastewater stream maybe attributed to use of brass (copper and zinc), copper scrubbers and iron wire in the cleaning of kitchen pots and pans in the households. Malamulele is a rural town with no heavy industries.

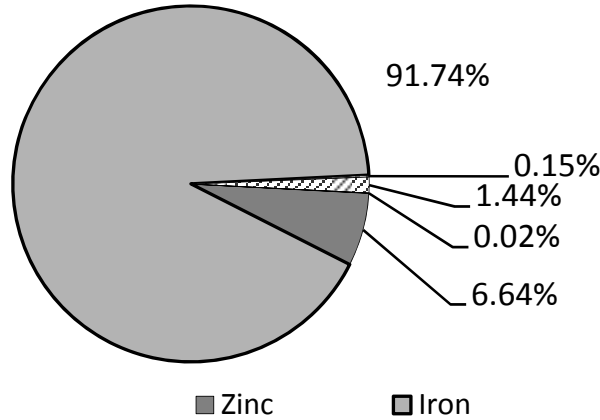

Figure 3: Heavy metal composition of sludge.

The presence of lead and cadmium is worrisome since these are toxic metals that are hazardous to humans and the environment (Nweke and Sanders III [23]). In South Africa, leaded fuels have been phased out and may be residues of the $\mathrm{Pb}$ are still persistent in the environment (Nweke and Sanders III [23]). 
Although the heavy metal content of final effluent was rich in lead, copper, iron and zinc, the levels were within the special and general standards for effluent discharge (Table 2). The extent of removal also varied among the metals. Chipasa [3] noticed the same variations on a study of the accumulation and fate of selected heavy metals in a biological wastewater treatment system. The wastewater treatment system was found to be more efficient on the removal of iron, zinc and lead since low levels were detected in the effluent than in the influent (Figure 4). The zinc removal efficiency was mixed, ranging between $18 \%$ and $87 \%$, with an average of $57 \%$ (Figure $4(\mathrm{a})$ ). The removal of $\mathrm{Zn}$ seemed to be reduced when the summer season approaches. The iron removal efficiency was remarkable with a high value of $91 \%$ and a minimum of $81 \%$ with an average removal efficiency of $85 \%$ (Figure 4(b)). But on 15 January 2008 the biological water treatment system failed to remove iron since the effluent was rich in iron. The conditions within the wastewater treatment system were probably favourable for the removal of Fe since it failed to either adsorb onto solid particles or other matrices. Figure 4(c) showed that most $\mathrm{Pb}$ was not detected in the effluent only with the exception of the $23^{\text {rd }}$ of October 2007 for which its source remained unknown. $\mathrm{Pb}$ attained a marginal removal efficiency

(a)

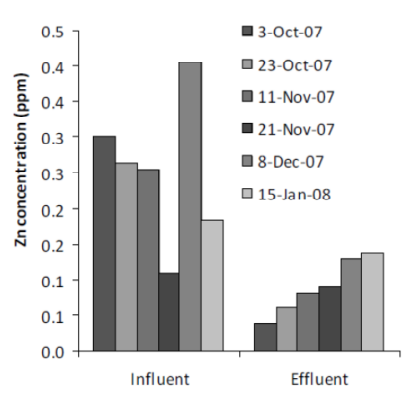

(c)

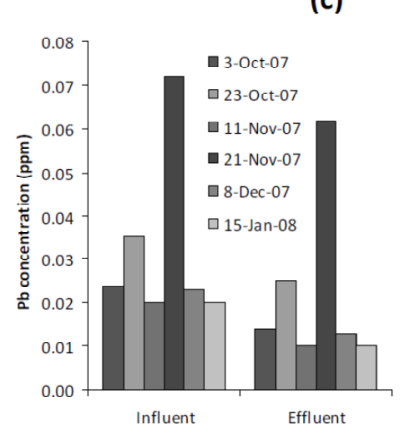

(b)

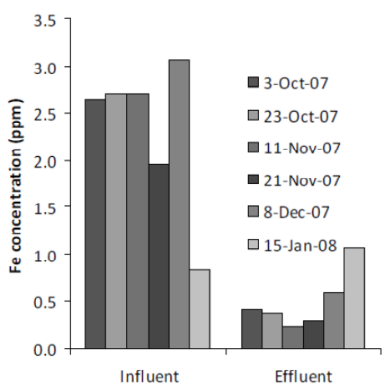

(d)

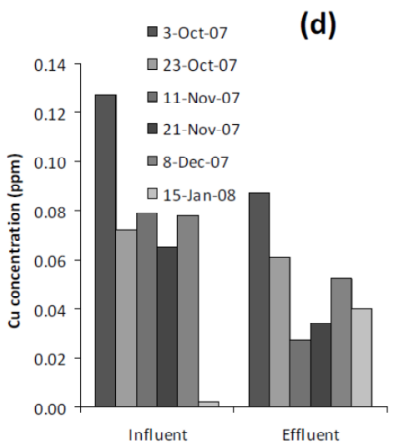

Figure 4: Comparison of heavy metal removal in influent and effluent samples. (Mean concentration \pm standard deviation of triplicate samples). 
ranging between $14 \%$ and $50 \%$ with an average of $38 \%$. Thus, biological waste water treatment plant was therefore unable to reduce $\mathrm{Pb}$ from the final effluent due to its removal in very little amounts. The concentrations of $\mathrm{Zn}$ and Iron were higher than that of $\mathrm{Cu}$ and $\mathrm{Pb}$ in the system. With copper the removal efficiency was mixed and ranged between $15 \%$ and $66 \%$, with an average removal efficiency of $39 \%$ (Figure 4(d)). This shows that a large quantity of copper was not removed by the system as shown by decrease in $\mathrm{Cu}$ in the effluent by $0.1 \mathrm{ppm}$ on the $23^{\text {rd }}$ of October 2007. This showed that conditions within the system were not favourable for the removal of $\mathrm{Cu}$ since it failed to either adsorb solid particles or other matrices in the system.

The heavy metals present in the water were removed by the wastewater treatment system since very low concentrations were observed in the effluent. The behaviour of metals within the system generally showed no pattern, especially for copper removal. Chipasa [3] reported, on the basis of his/her study that, the removal of heavy metals from wastewater was influenced by their initial contents in the influent stream. This is also confirmed in this study but only for $\mathrm{Fe}, \mathrm{Zn}$ and $\mathrm{Pb}$. Mulkerrins et al. [24] indicated that operating parameters, physical, chemical and biological factors affect the removal of heavy metals within the system. Therefore, in this study these conditions were not conducive for the removal of $\mathrm{Cu}$ but conducive for the removal other metals.

Heavy metals are soluble in water under acidic conditions, which may determine their removal in wastewater (Wong et al. [25]). Biological wastewater treatments operate ideally in the $\mathrm{pH}$ range of 7 to 9 . In this study the $\mathrm{pH}$ range was 6.3 to 7.2 and this may have, has, to some extent, influenced the removal efficiency of some heavy metals. In this $\mathrm{pH}$ range, heavy metals may have differing solubility and since composition of the matrix is complex and varying, removal variation may be attributed to these factors.

\subsection{The effect of Malamulele WWTP effluent on Mandzoro River water quality and the distribution of aquatic macroinvertebrates}

The average Score Per Taxon (ASPT) for the upstream section on 03 October 2007 was 6.3 and SASS score was 25. According to Chutter [26] these findings suggest that the water quality of this river was in a pristine condition, with reduced habitat diversity. The second sampling of January 2008 found an increased ASPT score of 6.8 and SASS score of 27. In the downstream section, the ASPT and SASS scores were considerably reduced to 2.7. The differences in ASPT and SASS scores between the upstream and downstream sections suggests that there was a major deterioration in water quality, which may have been as a result of inflows of effluent (Chutter [26]). Similar results were recorded in the second sampling of January 2008. These findings also suggest that the coming of the rainfall seasons may have a limited impact (dilution of upstream water) on water quality deterioration that was observed on the downstream section.

There was no change in the number of families living in both upstream and downstream sections of Mandzoro River. However, there was a change in the SASS score for the upstream section on January 15, 2008. Intolerant families may have been encouraged to colonise the site due to the increase in the flow of 
the river as the rainy season approached. The SASS score for the downstream section was similar in both sampling periods. This shows that the effluent had an effect on the downstream water quality; therefore, it was difficult for other species to colonise the site. These findings differ with Chutter [26], who reported changes on the number of families due to salt solution discharge in the river.

This study found out that it is not always the case that the introduction of pollutants in the river may lead to changes in the number of families. However, an introduction of pollutants may lead to replacement of the types of families. Dallas et al. [27] reported that the changes in aquatic macroinvertebrates assemblage downstream of the wastewater treatment facility were due to family replacement. In this case, the assemblage consists of different families. Therefore, change in assemblage meant change in the type of families and this was what this study has also found. Thiaridae and Belostomatidae were found on $3^{\text {rd }}$ October 2007 but on the $15^{\text {th }}$ of January 2008, they were not found instead Dysticidae and Psychodidae were found. Aquatic macroinvertebrates responded relatively quickly to changes in conditions of a river. Their life cycle duration permitted them to adapt from short to medium term impacts on water quality.

\section{Conclusion}

It has been found that large quantities of heavy metals were removed with sludge. The Malamulele Wastewater Treatment Plant was found to be inefficient in the removal of copper and lead. The sludge was found to be unsuitable for agricultural purposes due to high content of heavy metals. Overall, heavy metal concentration in the sludge was found in the following increasing order: $\mathrm{Cd}<\mathrm{Pb}<\mathrm{Cu}<\mathrm{Zn}<\mathrm{Fe}$. Cd was detected in neither effluent nor influent but detected in the sludge in very low concentration. It has been seen that the higher concentration of heavy metals in the influent resulted in their higher removal rate. Pollution resistant aquatic macroinvertebrates, Psychodidae and Thiaridae were only found in the downstream section of Mandzoro River. Thus, the Malamulele sewage plant was contributing to the deterioration of water quality of Mandzoro River downstream of the discharge point.

\section{Acknowledgements}

The University of Venda is acknowledged for their financial support for conference attendance at the $12^{\text {th }}$ International Conference on Modelling, Monitoring and Management of Water Pollution, the Algarve, Portugal. We are also grateful to the operating staff at Malamulele WTP for allowing us to collect water samples.

\section{References}

[1] G. Morrison, OS. Fatoki, S. Linder and C. Lundehn, (Determination of Heavy Metal Concentrations and Metal Fingerprints of Sewage Sludge 
from Eastern Cape Province, South Africa by Inductively Coupled Plasma - Mass Spectrometry (ICP-MS) and Laser Ablation-Inductively Coupled Plasma-Mass Spectrometry (LA-ICP-MS). Water, Air, Soil Pollut., 2004, 152(1-4), 111-127.

[2] Mathee A and Von Schirndling Y. The Risk of Environmental Lead Exposure amongst South African Children, Medical Research Council and World Health Organisation, South Africa, 2002.

[3] Chipasa BK., Accumulation and Fate of Selected Heavy Metals in a Biological Wastewater Treatment System. Waste Management 23, 135143, 2003.

[4] Eccles H., International Biodeterioration \& Biodegradation, Elsevier Science Limited, Great Britain, 1995.

[5] Davies BR and Day JA. Vanishing waters, University of Cape Town press, Cape Town, South Africa, 1998.

[6] Anon, Removal of pollutants from wastewater [Internet], Flush Gordon's Secret Identity, UK. Available from:_http://www.geocities.com/RainForest /5161/wwtps.htm 1997 [Accessed: 06 March 2008]

[7] WHO and UNEPA. Water Quality in Perspective, WHO, Geneva, 1989.

[8] Horan NJ, Biological Wastewater Treatment System: Theory and Operation, John Wiley, Chichester, 1990.

[9] Gumbo JR, Malaka EM, Odiyo JO and Nare L., The Health Implications of Wastewater Reuse in Vegetable Irrigation: A Case Study from Malamulele, South Africa. Inter Journal of Environmental Health Research, 20(2), 1-11, 2010.

[10] APHA, AWWA, EFA. Standard Methods for the Examination of Water and Wastewater, Washington, DC, USA, 1998.

[11] Hseu, ZY., Chen, ZS., Tsai, CC., Tsui, CC., Cheng, SF., Liu, CL., Lin, HT., Digestion methods for total heavy metals in sediments and soils. Water Air Soil Pollut. 141, 189-205, 2002.

[12] Dickens CWS and Graham PM, The South African Scoring System Version 5, Rapid Bioassessment Method for Rivers, African Journal of aquatic sciences 27: 1-10, 2002.

[13] DWAF, South African Water Guidelines, Volume 8, Field Guide, 1996.

[14] Koning N and Ross JC., The continued influence of organic pollution on the water quality of the turbid Modder River. Water S.A. 25:3: 285-292, 1999.

[15] Singh SN, Srivastava G, Bhatt A., Physicochemical Determination of Pollutants in wastewater in Dheradun. Curr World Environ (1): 133-138, 2012.

[16] DWAF, South African Water Quality Guidelines, Volume 1, Domestic Use, 1996.

[17] O’Loughlin EJ, Kelly SD, Kemmer KM, Csencsito R, Cook RE., Reduction of $\mathrm{Ag}^{\mathrm{I}}, \mathrm{Au}^{\mathrm{III}}, \mathrm{Cu}^{\mathrm{II}}$, and $\mathrm{Hg}^{\mathrm{II}}$ by $\mathrm{Fe}^{\mathrm{II}} / \mathrm{Fe}^{\mathrm{III}}$ Hydroxysulfate Green Rust, Chemosphere 53: 437-446, 2003. 
[18] Fatoki OS, Gogwana P and Ogunfowokan AO., Pollution assessment in the Kieskamma River and in the impoundment downstream. Water S.A. 29:2: 183-187, 2003.

[19] Dallas FHA and Day JA., Effects of Water Quality Variables on Riverine Biota, Water Research Commission. Final Report No. 351/1/94, 217-234. 1994.

[20] DWA, Important announcement on implementation of Special Phosphate standard in sensitive catchments. IMIESA (Johannesburg). 13(9), 35, 1988.

[21] Makhera M, Gumbo JR, Chigayo K., Monitoring of microcystin-LR in Luvuvhu River catchment: Implications for human health. African Journal of Biotechnology, 10(3), 405-412, 2011.

[22] Codd GA., Cyanobacterial toxins, the perception of water quality, and the prioritisation of eutrophication control. Ecological Engineering. 16, 51-60, 2000.

[23] Nweke OC and Sanders III WH., Modern Environmental Health Hazards: A Public Health Issue of Increasing Significance in Africa, Environ Health Perspect. 117, 863-870, 2009.

[24] Mulkerrins D, Dobson ADW and Colleren E., Parameters affecting biological phosphate removal from wastewaters. Environment International 30: 249-259, 2004.

[25] Wong JWC, Xiang L, Gu XY, and Zhou LX., Bioleaching of heavy metals from anaerobically digested sewage sludge using $\mathrm{FeS}_{2}$ as an energy source, Chemosphere 55: 101-107, 2004.

[26] Chutter FM., Research on the Rapid Biological Assessment of Water Quality Impacts in Streams and Rivers. Report to the Water Research Commission, Enviromentek, CSIR. WRC report No. 422/1/98. 1998.

[27] Dallas HF, Janssens MP and Day JA., An Aquatic Macroinvertebrates and chemical Database for Riverine Ecosystems. Water S.A. 25: 1: 1-8, 1999. 